\title{
SIMULATION OF PARAMETERS INFLUENCING THE ELECTRIC VEHICLE RANGE
}

Increasing the range of electric vehicles is crucial for electromobility expansion. Using the simulation it is possible to identify the parameters that have a significant impact on the electric vehicle range. Therefore, the analysis of parameters influencing the range was created. Simulation was based on real driving cycles for better accuracy.

Keywords: Electric vehicle, range, simulation, driving cycle.

\section{Introduction}

E-mobility importance in the world has been continuously growing. The range of electric vehicles is considered a major barrier to the acceptance of e-mobility [1]. The battery is the most important component for increasing the range of electric vehicles. New technologies can improve specific energy of the batteries. Also lightweight materials are increasing the electric vehicle range. Another possibility for increasing the range is the use of a range extender [2]. It is a combustion engine which charges the batteries via generator [ 3 and 4 ].

Simulations were created in Matlab/Simulink to analyse the parameters affecting the range. Real route as an input to the simulation for better accuracy was used. Routes were measured by using the experimental vehicle Edison.

\section{Electric vehicle simulation}

Matlab/Simulink was chosen for the simulation. Simulink is an extension of Matlab for modelling and simulation of dynamic systems. The electric vehicle model consists of five main subsystems. Inputs to the simulation are measured data from a real driving cycle. Demanded power is calculated in the dynamic subsystem based on chosen parameters of the vehicle. Speed and efficiency characteristics are defined in the electric motor model by using a lookup table. Efficiency characteristic is defined for the motor and generator mode and takes into account losses in the controller. Discharging and charging of the battery is controlled in the control strategy subsystem. Battery behaviour is determined in the battery subsystem [5, 6, 7, 8 and 9].

The demanded power for vehicle propulsion supplied from the battery is calculated by equation (1).

$P_{z a k u}=\left[m \frac{d v}{d t} \lambda+m g(\sin \alpha+f \cos \alpha)+\frac{1}{2} c_{x} S_{x} \rho v^{2}\right] \frac{v}{\eta}$

where $v$ is the speed of the vehicle, $m$ is the weight, $\lambda$ is the rotational inertia factor, $\alpha$ is the road angle, $\mathrm{f}$ is the rolling resistance coefficient, $\mathrm{c}_{\mathrm{x}}$ is the aerodynamic drag coefficient, $\mathrm{S}_{\mathrm{x}}$ is the frontal area, $\rho$ is the air density, $\eta$ is the efficiency of the drive, where is included the efficiency of the individual elements of the drive such as electric motor and mechanical efficiency [10].

Power provided via recuperation kinetic energy during braking is calculated:

$P_{d o \_a k u}=\left[m \frac{d v}{d t} \lambda+m g(\sin \alpha+\cos \alpha)+\frac{1}{2} c_{x} S_{x} \rho v^{2}\right] \frac{v}{\eta}$

Total energy flow $E_{b a t}$ to the battery is expressed by the formula (3).

$E_{b a t}=\int P_{z_{\_} a k u} d t-\int P_{d o \_a k u} d t$

The resulting range of electric vehicle to the battery discharge is expressed:

$s=\int_{100 \% S O C}^{O \% S O C} v d t$

\footnotetext{
* '1Lubos Kucera, ${ }^{2}$ Igor Gajdac, ${ }^{2}$ Martin Mruzek

${ }^{1}$ Department of Design and Mechanical Elements, Faculty of Mechanical Engineering, University of Zilina, Slovakia

${ }^{2}$ University Science Park, University of Zilina, Slovakia

E-mail: lubos.kucera@fstroj.uniza.sk, igor.gajdac@uvp.uniza.sk, martin.mruzek@uvp.uniza.sk
} 


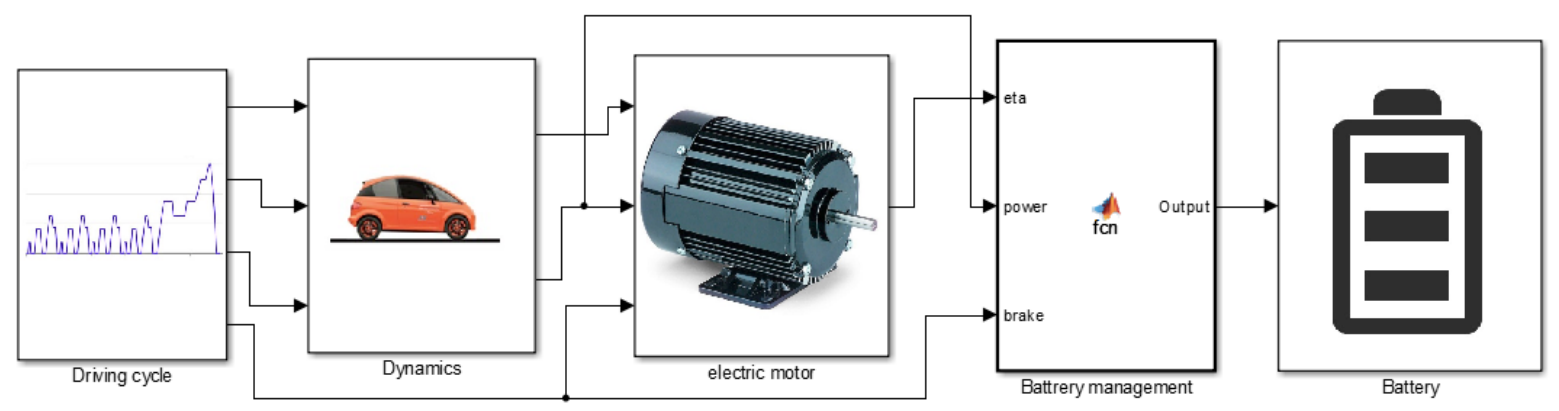

Fig. 1 Electric vehicle model

In Figure 1 is shown the model of the electric vehicle created in Simulink.

\section{Real driving cycle}

A driving cycle is defined as a speed of a vehicle versus time. Standardised cycles for measuring fuel consumption and harmful emissions are used for the vehicle simulations. However, these cycles are simplified and do not reflect reality [11]. Driving cycles were chosen as an input to the simulation in order to reach the reality. The measurement of driving cycles was performed by the experimental electric vehicle Edison, which allows data logging of dynamic parameters. The Edison was made at the University of Zilina. Curb weight of the vehicle is $1048 \mathrm{~kg}$ including batteries. Propulsion is provided by a compact lightweight aluminium, aircooled asynchronous electric motor AKOE with a nominal output of $16 \mathrm{~kW}$ and maximum power of $30 \mathrm{~kW}$, with CURTIS controller and LiFeYPO4 300Ah batteries. The main part of the vehicle is a tubular steel space frame [12].

Two real routes were chosen to the simulations. Route 1 (Fig. 2) consists of driving in a city and its surroundings. The maximum speed on route 1 was $76.5 \mathrm{~km} . \mathrm{h}^{-1}$ and the average speed was 41.5 $\mathrm{km} . \mathrm{h}^{-1}$. Route 2 was (Fig. 3) measured only in the city traffic. The maximum speed on route 2 was $50.2 \mathrm{~km} \cdot \mathrm{h}^{-1}$ and the average speed was $18.6 \mathrm{~km} \cdot \mathrm{h}^{-1}$.

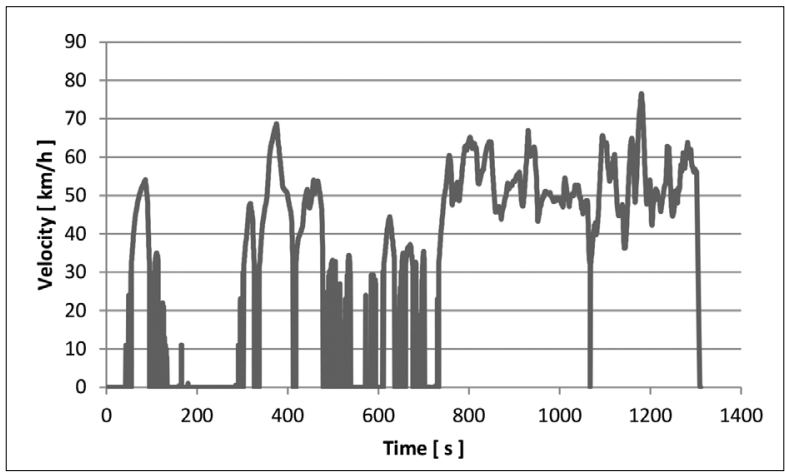

Fig. 2 Course of speed on route 1

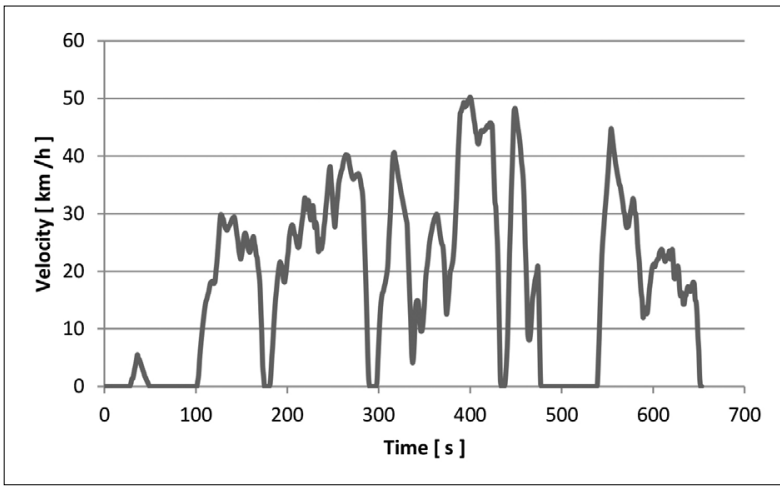

Fig. 3 Course of speed on route 2

\section{Analysis of parameters influencing the range}

The electric vehicle Edison can also measure energy consumption via its data logging system. Therefore, it is possible to compare the results of simulation with reality. Construction parameters of the experimental vehicle Edison were selected as an input to the simulation. To the curb weight of the EDISON was added the weight of two passengers and cargo. The total vehicle weight was $1250 \mathrm{~kg}$. The $24 \mathrm{kWh}$ battery pack was chosen. It was selected lithium battery with capacity of $24 \mathrm{kWh}$. The battery was not discharged below $10 \%$. Nominal power of the electric motor was $16 \mathrm{~kW}$.

Validation of the model with reality was performed on routes 1 and 2. Real energy consumption of the electric vehicle $15.41 \mathrm{kWh} / 100 \mathrm{~km}$ was measured on route 1 . Simulated energy consumption of the electric vehicle was $15.56 \mathrm{kWh} / 100 \mathrm{~km}$ on route 1 . In the second case real energy consumption 13.81 $\mathrm{kWh} / 100 \mathrm{~km}$ was measured on route 2. Simulated energy consumption was $14.35 \mathrm{kWh} / 100 \mathrm{~km}$ on route 2 . The difference between reality and simulation was $1 \%$ on route 1 and $3.9 \%$ on route 2. Impact on the electric vehicle range was simulated on these models with various weights and various aerodynamic drag coefficients. Also the impact of low temperatures was simulated on the range. 


\section{Impact of weight}

One of the possibilities to increase the range is to reduce the vehicle weight. Figure 4 shows the impact of vehicle weight on the range and Fig. 5 shows the impact of the weight on energy consumption.
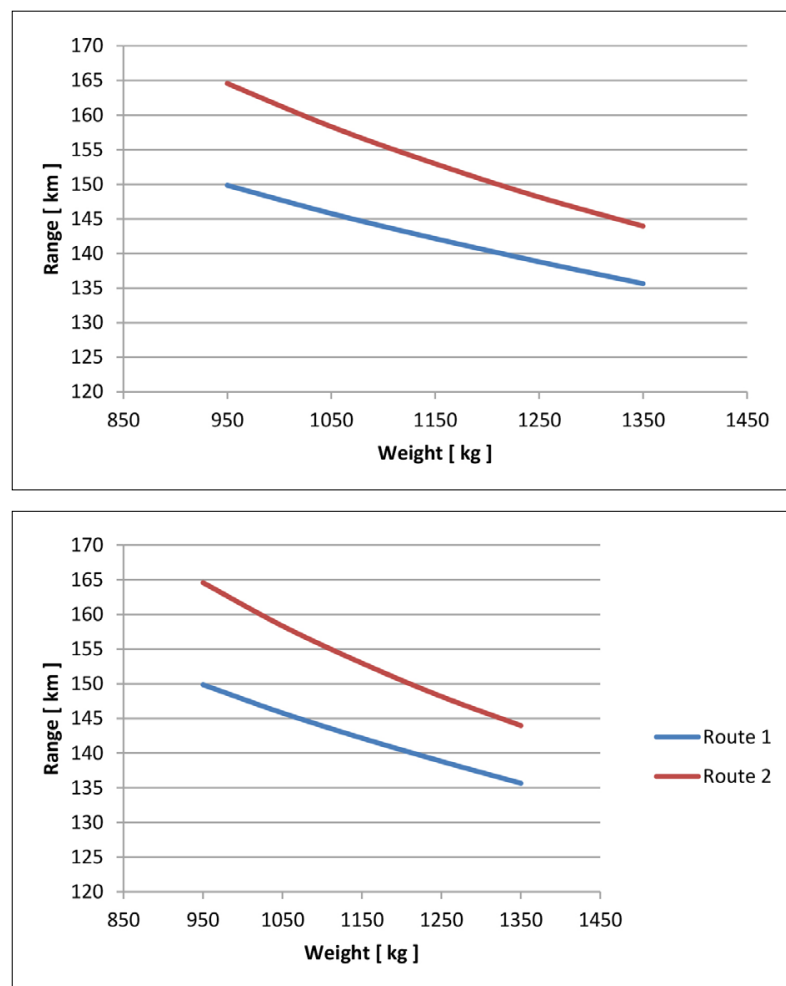

Fig. 4 Impact of weight on the range

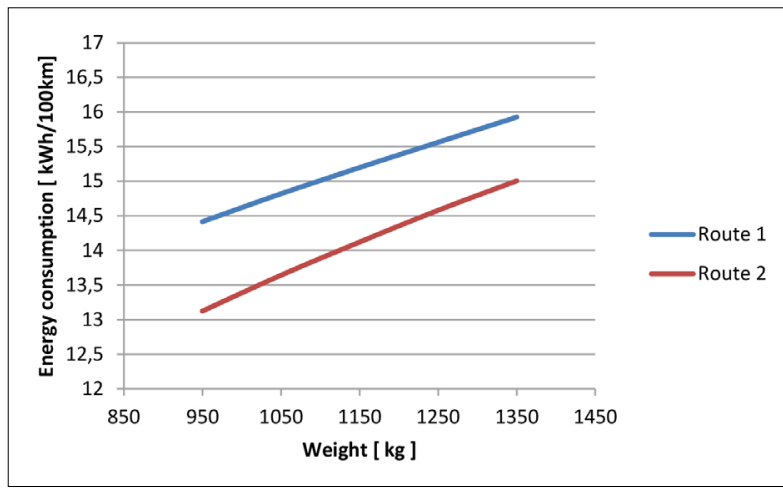

Fig. 5 Impact of weight on energy consumption

\section{Impact of aerodynamic drag coefficient $c_{x}$}

The aerodynamic drag coefficient value is commonly 0.32 for city vehicles. As you can see in Fig. 6, the aerodynamic drag coefficient had a bigger impact on the range on route 2 because aerodynamic drag rises quadratically with speed. The average speed on route 2 was $18.6 \mathrm{~km} \cdot \mathrm{h}^{-1}$ and on route 1 was $41.5 \mathrm{~km} \cdot \mathrm{h}^{-1}$.

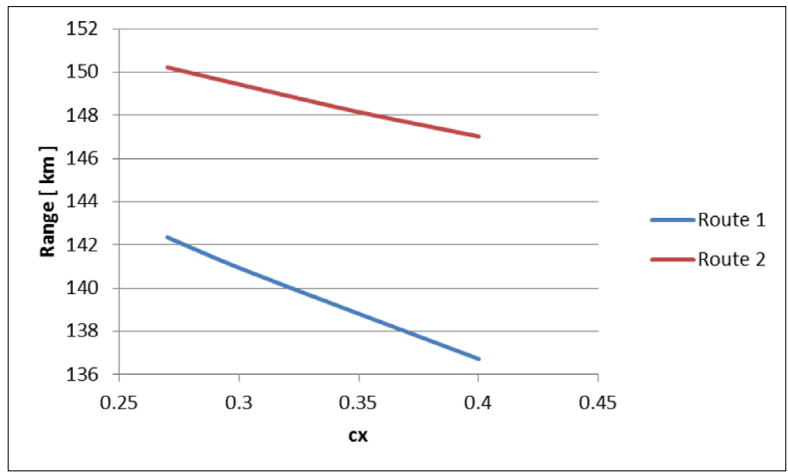

Fig. 6 Impact of $c_{x}$ on the range, $1250 \mathrm{~kg}$ vehicle weight

Figure 7 shows the impact of $c_{x}$ on energy consumption.

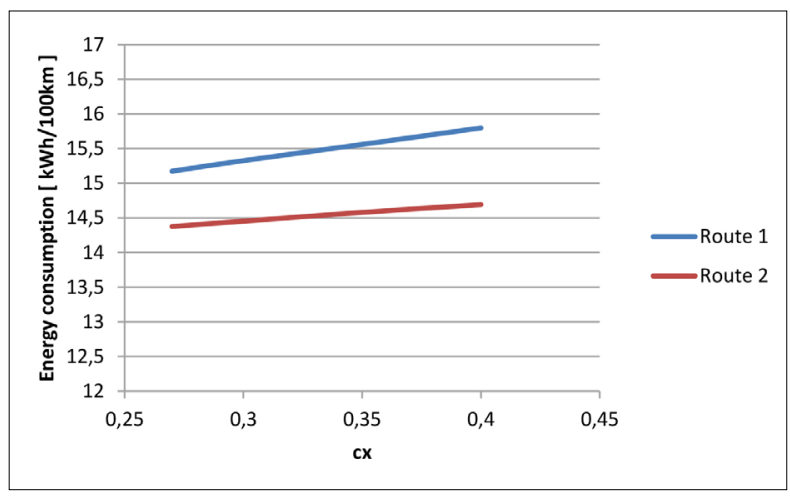

Fig. 7 Impact of $c_{x}$ on energy consumption, $1250 \mathrm{~kg}$ vehicle weight

\section{Impact of low temperature}

The electric vehicles suffer from significant range loss in sub-zero temperatures. The poor performance of Lithium cells at sub-zero temperatures implies significantly increased internal resistance [13, 14 and 15]. Figure 8 shows behaviour of LiFeYPO4 battery at $0^{\circ} \mathrm{C}$ and $18^{\circ} \mathrm{C}$ temperature when vehicle needed power of $10.4 \mathrm{~kW}$ for propulsion. Low $0^{\circ} \mathrm{C}$ temperature caused the battery voltage drop and current increasing. The battery model was modified for low temperatures impact simulation. The battery model was modified based on the testing of EV Edison at $0{ }^{\circ} \mathrm{C}$ at the University of Zilina campus. Figure 9 shows how the range which was simulated on the route 1 changed when the temperature was $0{ }^{\circ} \mathrm{C}$. The simulation shows that the range is decreased approximately by 7.5 kilometres in all weight variations. It should be noted that the simulation did not take into account energy which is needed for heating the passenger area. In Figure 10 you can see that energy consumption increased approximately by $0.8 \mathrm{kWh} / 100 \mathrm{~km}$ due to low temperature. 


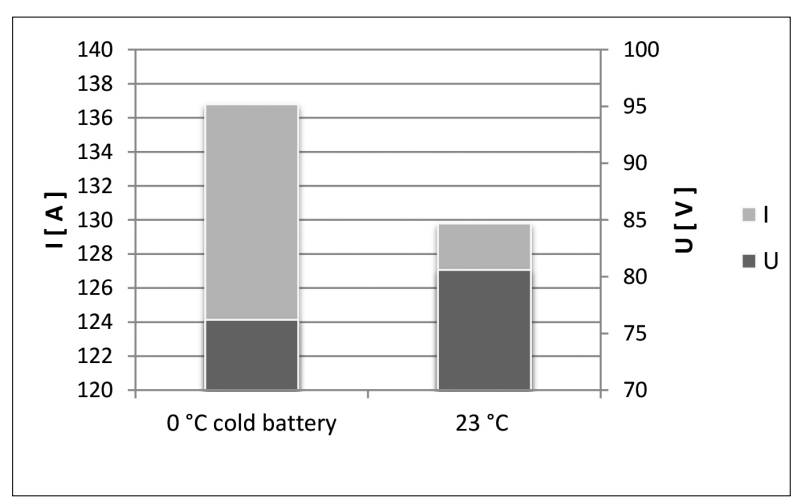

Fig. $8 \mathrm{LiFeYPO} 4$ battery producing $10.4 \mathrm{~kW}$ at $0^{\circ} \mathrm{C}$ and $18^{\circ} \mathrm{C}$

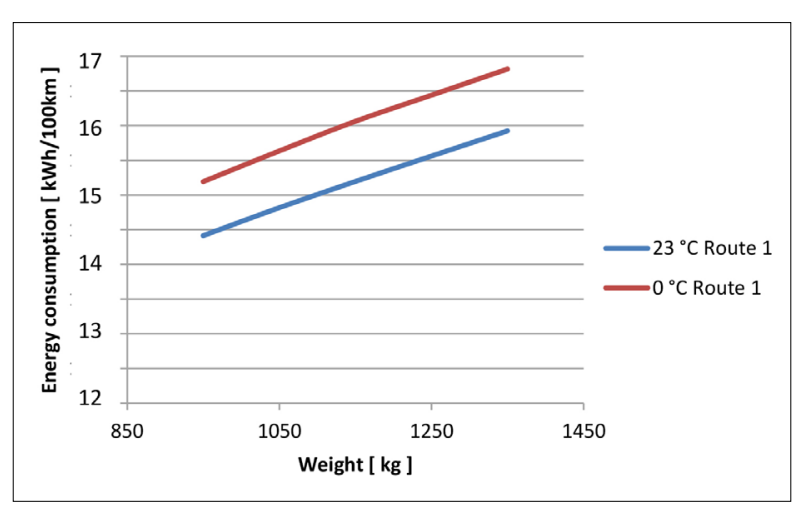

Fig. 10 Impact of low temperatures on energy consumption

\section{Conclusion}

The simulation results show that for increasing the range of city electric vehicles it is better to focus on decreasing the

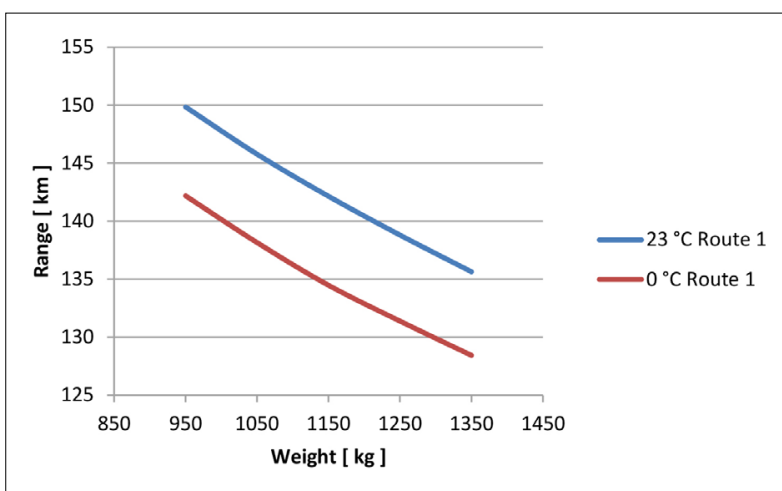

Fig. 9 Impact of low temperatures on the range

weight rather than the aerodynamic drag coefficient. Climatic conditions especially low temperatures have significant impact on the range of electric vehicles. When designing electric vehicles it is also beneficial to focus on the systems which can heat the batteries to the appropriate temperature when the battery has low internal resistance. The gained results from simulations, mainly from the simulations of low temperature impact will be used in development of the on-board systems which will inform the driver about the range with better accuracy.

\section{Acknowledgement}

This paper is supported by the following project: University Science Park of the University of Zilina (ITMS: 26220220184) supported by the Research\&Development Operational Program funded by the European Regional Development Fund and APVVSUSPP-014-09 - Centrum komponentov dopravnej techniky.

\section{References}

[1] FRANKE, T., NEUMAN, I., BUHLER, F., COCORON, P., KREMS, J. F. K.: Experiencing Range in an Electric Vehicle -understanding Psychological Barriers, Applied Psychology: An International Review, 61(3), 2012, 368-391.

[2] Derollepot, R., WeisS, C., KOlli, Z., FrANKe, T., TRIGUi, R., CHLOND, B., ARMOOGUM, J., STARK, J., KLEMENTSCHITZ, R., BAUMANN, M., PELISSIER, S.: Optimizing Components Size of an Extended Range Electric Vehicle According to the Use Specifications, Transport Research Arena, 2014, Paris.

[3] BARTA, D., GALIKOVA, J.: Wheeled Vehicles - Trolleybuses and Alternative Drives (in Slovak). Zilinska univerzita: Zilina, 2013, ISBN 978-80-554-0751-7.

[4] HLAVNA, V., KOVALCIK, A.: Energy Sources for Automobiles Nonconventional (in Slovak), Zilinska univerzita, vol. 1, 2013, ISBN 978-80-554-0788-3.

[5] BRUMERCIK, F., LUKAC, M.: Vehicle Simulation Possibilities, Logi: Scientific Journal on Transport and Logistics, vol. 3, 2012, 45-52, ISSN 1804-3216.

[6] GAO, D. W., MI, CH., EMADI, A.: Modeling and Simulation of Electric and Hybrid Vehicles, Proc. of the IEEE, 200, 729-745.

[7] NAEHYUCK, CH., DONKYU, B., JEONGMIN, H.: Power Consumption Characterization, Modeling and Estimation of Electric Vehicles, 2014 IEEE/ACM Intern. Conference, 2014, 175-182. 
[8] MAIA, R., SILVA, M., ARAUJO, R., NUNES, U.: Electric Vehicle Simulator for Energy Consumption Studies in Electric Mobility Systems, Integrated and Sustainable Transportation System (FISTS), 2011, ISBN 978-1-4577-0990-6, 227-232.

[9] SCHALTZ, E.: Electrical Vehicle Design and Modeling, INTECH, 2011, ISBN 978-953-307-477-1.

[10] EHSANI, M., GAO, Y., EMADI, A.: Electric and Fuel Cell Vehicles, CRC Press, Florida, 2010, ISBN 978-1-4200-5398-2.

[11] BARLOW, T. J., LATHAM, S., MCCRAE, I. S., BOULTER, P. G.: A Reference Book of Driving Cycles for Use in the Measurement of Road Vehicle Emissions. 3rd ed. TRL Limited, 2009.

[12] GAJDAC, I., MIKITA, M., KUCERA, L.: EDISON Project of Electric Vehicle at University of Zilina (in Slovak), AI magazine, 2014, 94-96.

[13] JI, Y., WANG, CH. Y.: Heating Strategies for Li-ion Batteries Operated from Subzero Temperatures, Electrochimica Acta, vol. 107, 2013, 664-674.

[14] BULLIS, K.: Electric Vehicles out in the Cold, MIT Technology Review, 2013.

[15] JOHNSON, V., PESARAN, A., SACK, T.: Temperature-Dependent Battery Models for High-Power Lithium-Ion Batteries, 17th Electric Vehicle Symposium Montreal, 2000. 